УДК 615.01+616-08+616.65-002

DOI https://doi.org/10.11603/2312-0967.2019.2.10161

\title{
СТАТИСТИЧНА ТА ФАРМАКОЕКОНОМІЧНА ХАРАКТЕРИСТИКА РЕЗУЛЬТАТІВ КЛІНІЧНИХ ДОСЛІДЖЕНЬ ЩОДО ЛІКУВАННЯ ХРОНІЧНОГО ПРОСТАТИТУ
}

\author{
І. В. Гадяк ${ }^{1}$, Б. П. Громовик ${ }^{2}$ \\ ДВНЗ «Івано-Франківський національний медичний університет»1 \\ Львівський національний медичний університет імені Данила Галицького ${ }^{2}$ \\ igadyak@ukr.net,hromovyk@gmail.com
}

ІНФОРМАЦІЯ

Надійшла до редакції / Received: 12.05.2019

Після доопрацювання / Revised: 15.05.2019

Прийнято до друку / Accepted: 20.05.2019

\section{Ключові слова}

хронічний простатит; антибіотики;

нестероїдні протизапальні засоби;

простатопротектори; клінічна ефрективність; еквівалентність, показник «шанси»; показник «витрати/ есрективність».

\section{АНОТАЦІЯ}

Мета роботи. Статистичне узагальнення даних клінічних досліджень (КД) лікарських засобів (ЛЗ), що використовуються при лікуванні хронічного простатиту (ХП), а також їх фрармакоекономічна оцінка.

Матеріали і методи. Матеріали дослідження: відомості Кокранівської бази контрольованих досліджень і веб-ресурсу Medline / PubMed Національної медичної бібліотеки США за 1995-2012 рр. щодо клінічної ефективності та безпеки антибіотиків (АБ), простатопротекторів (ПП) та нестероїдних протизапальних ЛЗ (НПЛЗ) при лікуванні ХП; дані Оранжевої книги Управління з контролю якості харчових продуктів та ЛЗ США (ОВ) і протоколів Комітету з Л3 для людини Європейського агентства Л3 (CHMP) та Rx index - Довідника еквівалентності Л3 про терапевтичну еквівалентність та/або біоеквівалентність Л3; інорормація програмного комплексу «Аптека» станом на січень 2019 р. про мінімальні закупівельні ціни ЛЗ.

Використано методи інформаційного пошуку, аналізу й синтезу, статистики та фрармакоекономіки, показник «шанси», а також індекс ХП Національного інституту здоров'я США для оцінки симптомів в КД (NIH-CPSI).

Результати й обговорення. Упорядковано дані опублікованих рецензованих, рандомізованих, плацебо-контрольованих КД із використанням NIH-CPSI як результату щодо застосування АБ, ПП і НПЛЗ при ХП. Статистичне узагальнення свідчить, що шанси АБ і ПП у КД знаходяться в межах 2,68...14,38 та 1,27 ...3,29 відповідно, тобто клінічний есрект швидше настане, ніж не настане. Встановлено, що при застосуванні Рофрекоксибу (шанси = $3,76)$ теж $є$ ймовірність настання клінічного ефекту.

Систематизовано інфрормацію про еквівалентність АБ, ПП і НПЛЗ для лікування ХП, які зареєстровані в Україні. Встановлено, що 3 торгові назви (TH) Левофлоксацину (з них одна ТН в двох дозах) присутні в переліку Rx index. Водночас Левофрлоксацин-Тева таб. п/о 500 мг №10 (Актавіс ЛТД, Мальта) знаходиться у двох аналізованих переліках (ОВ i Rx index). Окрім цього, показано, що одна ТН Силодозину наявна тільки в переліку CHMP. 3 двох ТН Фінастериду один ЛЗ Аденостерид-Здоров'я таб. 5 мг №30 (Здоров'я, Україна) присутній в Rx index, а інший Л3 Проскар таб. 5 мг №28 (Мерк Шарп і Доум Б.В., Нідерланди) - у двох досліджуваних переліках (OB i Rx index). Обчислено показник «вартість/ефрективність» для ТН Левофрлоксацину, Ципрофрлоксацину, Тамсулозину, Serenoa repens, Фінастериду, Силодозину та Рофекоксибу. При чому в АБ використали найнижчий показник клінічної

ISSN 2312-0967. Фармацевтичний часопис. 2019. № 2 
есрективності, а саме для Левофлоксацину - 92,0 \%, Ципрофрлоксацину $72,8 \%$, а в ПП - для ТН, у яких доведена клінічна ефективність понад $70 \%$. Висновки. Завдяки упорядкуванню інорормації КД щодо застосування Л3 при лікуванні ХП встановлено, що клінічна ефективність АБ складає 92,093,5 \% (Левофрлоксацин) і 72,8-76,8 \% (Ципрофрлоксацин), ПП - від 56,0 \% (Силодозин) до 76,7 \% (Л3 Serenoa repens), НПЛ3 Рофекоксибу - 79,0 \%. Встановлено, що ймовірність настання клінічного ефекту значно вища від ймовірності, що такий есрект не спостерігатиметься при лікуванні ХП АБ (шанси $=2,68 \ldots 14,38)$ і ПП (шанси $=1,27 \ldots 3,29)$. При цьому найкращий результат характерний для АБ Левосрлоксацину, помітно кращий - для ПП Serenoa repens, Фінастериду та Тамсулозину. За співвідношенням вартість/ ефрективність визначено, що станом на січень 2019 р. спостерігається клініко-економічна перевага застосування: в АБ серед ТН Левофлоксацину у Левофрлоксацинутаб. 500 мг № 14 (Астрафрарм, Україна)іТНЦипрофрлоксацину - Ципрофрлоксацину таб. 250 мг № 10 (ДЗ «ГНЦЛС», Україна); у ПП серед ТН Тамсулозину в Уримака капс. 0,4 мг № 30 (Маклеодс Фармасьютикалс Лімітед, Індія), ТН Фінастериду - Аденостериду-Здоров'я таб. 5 мг № 30 (Здоров'я, Україна) і ТН фрітопрепаратів - Простамолу ® уно капс. 320 мг № 30 (Берлін-хемі АГ, Німеччина). При цьому для Аденостериду-Здоров'я таб. 5 мг № 30 (Здоров'я, Україна) встановлений рівень еквівалентності.

Вступ. Простатит є поширеним урологічним діагнозом у чоловіків усіх вікових категорій, що становить 8 \% від обсягу відвідувань чоловічого урологічного відділення [1]. За класифрікацією Національного інституту здоров'я США (US National Institutes of Health, 1995 р.) існує чотири типи простатиту: гострий бактеріальний простатит; хронічний бактеріальний простатит; хронічний простатит абактеріальний, або синдром хронічного тазового болю (ХП / СХТБ), та асимптоматичний простатит (простатодинія). Простатит III типу $є$ найбільш поширений і становить 90-95 \% діагнозів простатиту [2]. Він традиційно асоціюється із запаленням у передміхуровій залозі, з інфекцією, що є ключовими етіологічними фракторами $[3,4]$. Основні прояви ХП зазвичай пов'язані з актом сечовипускання і включають часті поклики до сечовипускання та печіння або болю у сечовипускальному каналі. Тому проблема пошуку нових та вдосконалення чинних методик лікування хворих із різними фрормами ХП $є$ актуальною.

Мета роботи - статистичне узагальнення даних КД ЛЗ, що використовуються при лікуванні ХП, а також їх фрармакоекономічна оцінка.

Матеріали і методи. Матеріалами дослідження виступили відомості щодо ефективності та безпеки АБ, ПП та НПЛЗ при лікуванні ХП, отримані з Кокранівської бази контрольованих досліджень і вебpecypcy Medline/PubMed Національної медичної бібліотеки США (US National Library of Medicine, NLM) (1995-2012). Дані про терапевтичну еквівалентність та/або біоеквіалентність ЛЗ брали з Оранжевої книги (Orange Book, OB) Управління з контролю якості харчових продуктів та лікарських засобів США (Food and Drug Administration - FDA) [5], протоколів Комітету 3 ЛЗ для людини (Committee for Medicinal Products for Human Use, CHMP) Європейського агентства ЛЗ
(European Medicines Agency) [6] та Rx index - Довідника еквівалентності лікарських засобів (Rx index, Україна) [7].

Інформацію про мінімальні закупівельні ціни Л3 станом на січень 2019 р. отримали за допомогою програмного комплексу «Аптека» [8].

Використано методи інфоормаційного пошуку, аналізу і синтезу, статистики і фрармакоекономіки, а також індекс ХП Національного інституту здоров'я США (ХП (NIH-CPSI) для оцінки симптомів в КД $[9,10]$.

Для статистичної характеристики експериментальних непорівняльних КД використано показник «шанси» (odds, O) - вірогідність того, що подія станеться, виражена пропорційно до вірогідності, що події не буде [11]. Розраховується за фрормулою: $O=a / b$, де $a-$ число пацієнтів, у яких подія настала, $b$ - число пацієнтів, у яких подія не настала.

Інтерпретація значення величини шансу: $O=1$ - ймовірність настання події дорівнює ймовірності того, що подія не відбудеться; O > 1 - ймовірність настання події вища від ймовірності того, що подія не відбудеться; $O<1$ - ймовірність настання події нижча від вірогідності того, що подія не відбудеться.

Для обґрунтування достовірності використали:

- натуральний логарифрм шансів $\ln (O)=\ln \frac{a}{b}$;

- варіабельність $\operatorname{var}\left(\ln (O)=\frac{1}{a}+\frac{1}{b}\right.$;

$-\quad 95 \quad \% \quad$ довірчий інтервал
$\ln (\mathrm{O}) \pm 1,96 \times \sqrt{\operatorname{var}(\ln (\mathrm{O}))}$.

Якщо 95 \% ДІ не включає 1, тобто обидва значення меж або вище, або нижче 1, то виявлена залеж-

ISSN 2312-0967. Pharmaceutical review. 2019. № 2 
ність $€$ статистично значуща. У випадку наявності 1, тобто верхня межа більше 1, а нижня - менше 1, мова йде про відсутність статистичної значущості залежності. Чим вужчий інтервал 95 \% ДІ, тим більш істотною є виявлена залежність.

Показник (коефріцієнт) «витрати/ефективність» (cost/effectiveness ratio, CER) для КД розраховували за видозміненою фрормулою [13]: CER = CCT / Ef, де CCT - вартість курсу лікування, Ef - показник ефективності лікування.

Результати й обговорення. На першому етапі нашого дослідження упорядковано дані опублікованих рецензованих, рандомізованих, плацебо-контрольованих КД із використанням NIH-CPSI як результату щодо застосування АБ, ПП та НПЛЗ при ХП (табл. 1).

Встановлено, що застосування Левофлоксацину та Ципрофлоксацину є ефективними. Так, у КД [14], що включало 243 пацієнти, призначення Левофрлоксацину 500 мг один раз на день протягом 28 днів показало статистично значущі поліпшення в кінці терапії порівняно 3 вихідними даними щодо клінічних симптомів дизурії, хворобливої еякуляції, промежини, непрохідності сечі, болю передміхурової залози під час пальпації та кількості лейкоцитів. Наприкінці лікування показники клінічного успіху становили 93,5 \%. Побічні реакції (ПР) були зареєстровані у 3 хворих.

Результати іншого КД [15], в якому брали участь 117 пацієнтів, показали, що 28-денна терапія Левофолоксацином у дозі 500 мг один раз на добу привела до поліпшення симптомів у $92 \%$ хворих із діагнозом ХП. Лише чотири пацієнти (3,4 \%) припинили терапію внаслідок ПР.

У КД [16] 28-денний курс лікування Ципрофлоксацином (n=189) показав клінічну есрективність у 72,8 \%. КД [17] щодо застосування Ципрофрлоксацину 500 мг двічі на день упродовж місяця $(\mathrm{n}=30)$ показали задовільні результати лікування у 76,8 \%. ПР зареєстровані у 8 пацієнтів (26,6 \%). Припинення прийому Л3 заоріксовано лише в одного пацієнта. В обох зазначених вище КД найбільш поширеними ПР були запаморочення, нудота і дискомфорт у шлунку.

Результати КД [18] 30 пацієнтів, які отримували щоденно 320 мг на добу екстракту плодів пальми сабаль (Serenoa repens) протягом 3 місяців, засвідчили поліпшення середнього значення NIH-CPSI 3 17,8 до 11,4 . Ефект покращення зареєстровано у 76,7 \% пацієнтів. Не було тяжких ПР. В одного хворого (3,3 \%) була помірна диспепсія, яка усунулася без припинення прийому ЛЗ.

Шість місяців проведеної терапії Фінастеридом 5 мг на добу $(n=31)$ для XП є безпечною і добре переноситься [19]. Наприкінці проведеного лікування $75 \%$ пацієнтів вказували на клінічне поліпшення. П'ять пацієнтів повідомили про ПР, пов'язані 3 фрармакотерапією.

КД щодо чотиритижневої терапії хворих ХП ( $\mathrm{n}=43)$ Тамсулозином 0,4 мг на добу показали зменшення показників NIH-CPSI на 5,5 бала, клінічний ефект отримали у 74,5 \% пацієнтів [20]. Ніяких серйозних ПР не спостерігали.

У КД щодо шестимісячної терапії Альфузозином у дозі 5 мг двічі на добу [21] для XП ( $\mathrm{n}=17)$ встановлено клінічне поліпшення у $65 \%$ хворих, а також зниження загального показника NIH-CPSI на 9,9 бала.

При фрармакотерапії ( $n=43)$ Теразозином у дозі 5 мг на добу упродовж 14 тижнів клінічну ефективність спостерігали у $60 \%$ хворих [22]. Зазначалося зниження на 14,3 бала у середньому загальному $\mathrm{NIH-CPSI} \mathrm{від} \mathrm{вихідного} \mathrm{рівня.} 18$ пацієнтів (42 \%) вказували на ПР.

\section{Таблиця 1}

Результати експериментальних непорівняльних КД щодо застосування АБ, ПП і НПЛЗ при лікуванні ХП

\begin{tabular}{|c|c|c|c|c|c|}
\hline Назва лЗ & Режим дозування & $\begin{array}{c}\text { Термін } \\
\text { лікування }\end{array}$ & $\begin{array}{c}\text { Число } \\
\text { хворих (n) }\end{array}$ & $\begin{array}{c}\text { Клінічна } \\
\text { есрективність, \% }\end{array}$ & Джерело \\
\hline \multicolumn{6}{|c|}{ AБ } \\
\hline \multirow[t]{2}{*}{ Левофрлоксацин } & \multirow{2}{*}{500 мг / добу } & \multirow{3}{*}{$\begin{array}{c}28 \text { днів } \\
\text { (4 тижні) }\end{array}$} & $n=243$ & 93,5 & Wagenlehner F et al [14] \\
\hline & & & $\mathrm{n}=117$ & 92,0 & Naber KG et al [15] \\
\hline \multirow[b]{2}{*}{ Ципросрлоксацин } & 500 мг /добу & & $\mathrm{n}=189$ & 72,8 & Bundrick W et al [16] \\
\hline & 500 мг двічі /добу & 30 днів & $\mathrm{n}=30$ & 76,8 & Trapeznikova MF et al [17] \\
\hline \multicolumn{6}{|c|}{ ПП } \\
\hline Serenoa repens & 320 мг / добу & 3 місяці & $n=30$ & 76,7 & Aliaev luG, et al [18] \\
\hline Фінастерид & 5 мг/добу & 6 місяців & $n=31$ & 75,0 & Nickel JC et al [19] \\
\hline Тамсулозин & 0,4 мг / добу & 4 тижні & $n=43$ & 74,5 & Chen XS et al [20] \\
\hline Альфрузозин & 5 мг двічі / добу & 6 місяців & $\mathrm{n}=17$ & 65,0 & Mehik A et al [21] \\
\hline Теразозин & 5 мг / добу & 14 тижнів & $\mathrm{n}=43$ & 60,0 & Cheah PY, et al [22] \\
\hline Силодозин & 4 мг / добу & 12 тижнів & $\mathrm{n}=52$ & 56,0 & Nickel JC et al [23] \\
\hline \multicolumn{6}{|c|}{ НПЛЗ } \\
\hline Рофекоксиб & 50 мг/добу & 6 тижнів & $n=53$ & 79,0 & Nickel JC et al [24] \\
\hline
\end{tabular}

ISSN 2312-0967. Фармацевтичний часопис. 2019. № 2 
Таблиця 2

Статистична обробка результатів щодо застосування АБ, ПП і НПЛЗ при лікуванні ХП

\begin{tabular}{|c|c|c|c|c|c|c|c|}
\hline Назва лЗ & $\begin{array}{c}\text { Число } \\
\text { хворих }\end{array}$ & $\begin{array}{c}\text { Клінічна } \\
\text { ефрективність, } \\
\%\end{array}$ & $\begin{array}{c}\text { Число хворих } \\
\text { без } 100 \% \\
\text { еректу }\end{array}$ & $\mathrm{O}$ & $\ln (\mathrm{O})$ & $\begin{array}{c}\text { var } \\
(\ln (O))\end{array}$ & $\begin{array}{c}95 \text { \% ДІ } \\
\text { In (О) }\end{array}$ \\
\hline \multicolumn{8}{|c|}{$\mathrm{AB}$} \\
\hline \multirow[t]{2}{*}{ Левофрлоксацин } & 243 & 93,5 & 16 & 14,38 & 2,666 & 0,068 & 2,$156 ; 3,176$ \\
\hline & 117 & 92,0 & 9 & 11,50 & 2,442 & 0,116 & 1,$774 ; 3,110$ \\
\hline \multirow{2}{*}{ Ципрофрлоксацин } & 30 & 76,8 & 7 & 3,31 & 1,197 & 0,187 & 0,$349 ; 2,044$ \\
\hline & 189 & 72,8 & 51 & 2,68 & 0,986 & 0,027 & 0,$666 ; 1,306$ \\
\hline \multicolumn{8}{|c|}{ ПП } \\
\hline Serenoa repens & 30 & 76,7 & 7 & 3,29 & 1,19 & 0,187 & 0,$343 ; 2,036$ \\
\hline Фінастерид & 31 & 75,0 & 8 & 3,00 & 1,098 & 0,172 & 0,$285 ; 1,911$ \\
\hline Тамсулозин & 43 & 74,5 & 11 & 2,92 & 1,071 & 0,122 & 0,$385 ; 1,757$ \\
\hline Альфрузозин & 17 & 65,0 & 6 & 1,86 & 0,62 & 0,259 & $-0,389 ; 1,601$ \\
\hline Теразозин & 43 & 60,0 & 17 & 1,50 & 0,405 & 0,097 & $-0,187 ; 1,037$ \\
\hline Силодозин & 52 & 56,0 & 23 & 1,27 & 0,239 & 0,078 & $-0,392 ; 1,012$ \\
\hline \multicolumn{8}{|c|}{ НПЛЗ } \\
\hline Рофекоксиб & 53 & 79,0 & 11 & 3,76 & 1,324 & 0,114 & 0,$661 ; 2,005$ \\
\hline
\end{tabular}

Після застосування 12-тижневої терапії ( $\mathrm{n}=52)$ Силодозином 4 мг на добу 56 \% пацієнтів повідомляли про помірне поліпшення [23]. Серед ПР найчастіше зустрічалась ретроградна еякуляція.

Єдине КД [24] показало, що тільки високі дози Рофекоксибу, а саме 50 мг надає клінічне поліпшення (79 \% 3 n=53). Спостерігали зниження на 4,9 бала у середньому загальному NIH-CPSI від вихідного рівня.

Відтак ми провели статистичну обробку результатів застосування АБ, ПП і НПЛЗ при лікуванні ХП.

Дані таблиці 2 підтверджують, що шанси АБ більші одиниці та знаходяться в межах 2,68...14,38. При чому найкращий результат $€$ у Левофлоксацину (O = 11,50...14,38). Результат шансів дворазового лікування Ципрофроксацином упродовж доби становить $(O=3,31)$ порівняно $з$ його одноразовим застосуванням ( $O=2,68)$, тобто кращий клінічний ефект має більше шансів наступити при дворазовому застосуванні на добу Ципрофллоксацину. Дані табл. 2 засвідчують, що шанси ПП більші одиниці та знаходяться в межах 1,27...3,29, тобто клінічний ефект швидше настане, ніж не настане. При цьому кращий результат притаманний Serenoa repens $(O=3,29)$ Фінастериду $(O=3,0)$ та Тамсулозину $(O=2,92)$ порівнян 3 Альфузозином (O=1,86), Теразозином $(O=1,50)$ та Силодозином 4 мг $(O=1,27)$. Статистична обробка показує, що при застосуванні Рофекоксибу $(O=3,76)$ теж $€$ ймовірність настання клінічного ефректу. Проте зазначена вище залежність $€$ статистично значущою при рівні $p<0,05$ лише для Левофрлоксацину, позаяк 95 \% ДІ не включає 1, значення його нижньої й верхньої меж понад 1. Для інших лЗ відсутня статистична значущість залежності при рівні р > 0,05, бо 95 \% ДІ включає 1, тобто його верхня межа більше 1 , а нижня - менше 1.

Далі ми систематизували інформацію про еквівалентність ТН АБ, ПП і НПЛЗ для лікування ХП, які зареєстровані в Україні (табл. 3). Встановлено, що три ТН Левофлоксацину (з них одна ТН в двох дозах) присутні в переліку Rx index. Водночас Левофрлоксацин-Тева таб. п/о 500 мг № 10 (Актавіс лтД, Мальта) знаходиться у двох аналізованих переліках (OB i Rx index). Окрім цього показано, що одна ТН Силодозину наявна тільки в переліку СНMР. 3 двох ТН Фінастериду один ЛЗ Аденостерид-Здоров'я таб. 5 мг № 30 (Здоров'я, Україна) присутній в Rx index, a iнший ЛЗ Проскар таб. 5 мг №28 (Мерк Шарп i Доум Б. В., Нідерланди) - у двох досліджуваних переліках (OB i Rx index).

Ми обчислили показник CER для тих ЛЗ, які характеризуються належними результатами КД (табл. 1) і терапевтичною еквівалентністю/біоеквівалентністю (табл. 3), а також зареєстровані в Україні та мали мінімальні закупівельні цінові пропозиції у програмному комплексі «Аптека». При цьому використали найнижчий показник клінічної ефективності в АБ, а саме для Левофрлоксацину - 92,0 \%, Ципрофлоксацину 72,8 \%. Щодо ПП, то обрані ЛЗ групи Serenoa repens, Фінастериду та Тамсулозину, позаяк у них доведена клінічна ефективність понад $70 \%$.

Значення показника CER показують (табл. 4), що за співвідношенням вартість/ефективність серед ТH Левофрлоксацину найбільш показаним $€$ Левослоксацин таб. п/о 500 мг № 14 (Астрафрарм, Україна) $(C E R=2,39)$ порівняно з іншими TH, а найменш вигідним $€$ Тайгерон® таб. п/о 500 мг № 5 (Кусум Хел-

ISSN 2312-0967. Pharmaceutical review. 2019. № 2 
Фармакоекономіка

Pharmacoeconomics

\section{Таблиця 3}

Інтерпретація еквівалентності АБ, ПП і НПЛЗ

\begin{tabular}{|c|c|c|c|}
\hline ТН, які зареєстровані в Україні & OB & $\mathrm{CHMP}$ & Rx index \\
\hline \multicolumn{4}{|l|}{ Левофлоксацин } \\
\hline Леволет таб. п/о 500 мг №10 (Д-р Редді'с Лабораторіс Лтд, Індія) & & & $\mathrm{B}_{1}$ \\
\hline Левофрлоксацин таб. п/о 250 мг і 500 мг №10 (Здоров’я, Україна) & & & $\mathrm{B}_{4}$ \\
\hline Левофрлоксацин-Тева таб. п/о 500 мг №10 (Актавіс ЛтД, Мальта) & $A B$ & & $\mathrm{~B}_{1}$ \\
\hline \multicolumn{4}{|l|}{ Силодозин } \\
\hline $\begin{array}{l}\text { Урорек капс. } 4 \text { мг і } 8 \text { мг №30 (Рекордаті Індустріа Хіміка е Фармасевтіка С.п.А,) } \\
\text { Італія }\end{array}$ & & + & \\
\hline \multicolumn{4}{|l|}{ Фінастерид } \\
\hline Аденостерид-Здоров'я таб. 5 мг №30 (Здоров'я, Україна) & & & $\mathrm{B}_{4}$ \\
\hline Проскар таб.5 мг №28 (Мерк Шарп і Доум Б.В., Нідерланди) & $A B$ & & A \\
\hline
\end{tabular}

\section{Таблиця 4}

Показники «витрати-есрективність» монотерапії ХП АБ, ПП і НПЛЗ

\begin{tabular}{|c|c|c|c|c|c|c|}
\hline ТН ЛЗ & 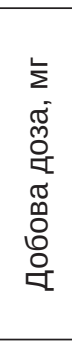 & 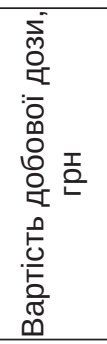 & 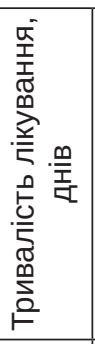 & 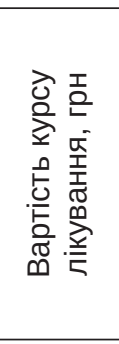 & 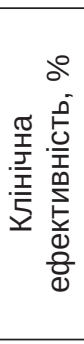 & 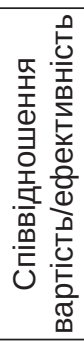 \\
\hline 1 & 2 & 3 & 4 & 5 & 6 & 7 \\
\hline \multicolumn{7}{|l|}{ Левофлоксацин } \\
\hline Левофрлоксацин таб. п/о 500 мг №14 (Астрафарм, Україна) & 500 & 7,85 & 28 & 219,80 & 92,0 & 2,39 \\
\hline Левофрлоксацин таб. п/о 500 мг №10 (Технолог, Україна) & 500 & 9,17 & 28 & 256,76 & 92,0 & 2,79 \\
\hline Левофрлоксацин таб. п/о 500 мг №7 (Астрафрарм, Україна) & 500 & 9,53 & 28 & 266,84 & 92,0 & 2,90 \\
\hline Левофрлоксацин-Тева таб. п/о 500 мг №10 (Актавіс лТД, Мальта) & 500 & 12,09 & 28 & 338,52 & 92,0 & 3,68 \\
\hline Флоксіум® таб. п/о 500 мг № 10 Київмедпрепарат, Україна & 500 & 12,21 & 28 & 341,88 & 92,0 & 3,72 \\
\hline Левосрлоксацин таб. п/о 500 мг №10 (Здоров'я, Україна) & 500 & 12,65 & 28 & 354,20 & 92,0 & 3,85 \\
\hline Левофлоксацин таб. п/о 250 мг №10 (Технолог, Україна) & 500 & 12,67 & 28 & 354,76 & 92,0 & 3,86 \\
\hline Леволет таб. п/о 500 мг №10 (Д-р Редді'с Лабораторіс Лтд, Індія) & 500 & 13,70 & 28 & 383,60 & 92,0 & 4,17 \\
\hline Левофлоксацин таб п/о 250 мг №10 (Здоров'я, Україна) & 500 & 14,34 & 28 & 401,52 & 92,0 & 4,36 \\
\hline Левофрлоцин500 таб. п/о 500 мг № 5 (Фарма Старт, Україна) & 500 & 14,66 & 28 & 410,48 & 92,0 & 4,46 \\
\hline Леваксела® таб. п/о 500 мг № 5 (КRКА, д.Д., Ново место, Словенія) & 500 & 15,06 & 28 & 421,68 & 92,0 & 4,58 \\
\hline Абіфрлокс таб. п/о 500 мг №10 (Ауробіндо Фарма Лімітед, Індія) & 500 & 15,22 & 28 & 426,16 & 92,0 & 4,63 \\
\hline $\begin{array}{l}\text { Локсофр таб. п/о } 500 \text { мг № } 5 \text { (Сан Фармасьютикал Індастріз } \\
\text { Лімітед, Індія) }\end{array}$ & 500 & 16,36 & 28 & 458,08 & 92,0 & 4,98 \\
\hline Левофрлокс таб. п/о 500 мг №5 (Скан Біотек, Індія) & 500 & 16,83 & 28 & 471,24 & 92,0 & 5,12 \\
\hline $\begin{array}{l}\text { Новокс®-500 таб. п/о } 500 \text { мг № } 5 \text { (Евертоджен Лайфр Саєнсиз } \\
\text { Лімітед, Індія) }\end{array}$ & 500 & 18,14 & 28 & 507,92 & 92,0 & 5,52 \\
\hline $\begin{array}{l}\text { Левостад® таб. п/о } 500 \text { мг № } 5 \text { (Стада Арцнайміттель АГ + } \\
\text { Лабораторіз Медікаментос Інтернатіонес, С.А., Німеччина) }\end{array}$ & 500 & 18,93 & 28 & 529,98 & 92,0 & 5,76 \\
\hline Ремедія таб. п/о 500 мг № 5 (Сімпекс Фарма, Індія) & 500 & 19,13 & 28 & 535,64 & 92,0 & 5,82 \\
\hline $\begin{array}{l}\text { Левоксимед таб. п/о } 500 \text { мг № } 7 \text { (Біофрарма Ілач Сан. Ве Тідж. } \\
\text { А.Ш., Туреччина) }\end{array}$ & 500 & 20,09 & 28 & 562,68 & 92,0 & 6,12 \\
\hline
\end{tabular}

ISSN 2312-0967. Фармацевтичний часопис. 2019. № 2 
Фармакоекономіка

Pharmacoeconomics

Продовження табл. 4

\begin{tabular}{|c|c|c|c|c|c|c|}
\hline 1 & 2 & 3 & 4 & 5 & 6 & 7 \\
\hline Левомак таб. п/о 500 мг № 5 (Маклеодс Фармасьютикалс Лімітед, Індія) & 500 & 20,38 & 28 & 570,64 & 92,0 & 6,20 \\
\hline Лефрлок таб. п/о 500 мг № 5 (Дарниця, Україна) & 500 & 21,77 & 28 & 609,56 & 92,0 & 6,63 \\
\hline Лебел таб. п/о 500 мг № 7 (Нобел Ілач санаї ве Тіджарет, Туреччина) & 500 & 24,14 & 28 & 675,92 & 92,0 & 7,35 \\
\hline Тайгерон® таб. п/о 500 мг № 5 (Кусум Хелтхкер пвт лтД, Індія) & 500 & 33,75 & 28 & 945,00 & 92,0 & 10,27 \\
\hline \multicolumn{7}{|l|}{ Ципрофрлоксацин } \\
\hline Ципрофрлоксацин таб. п/о 250 мг №10 (ДЗ «ГНЦЛС», Україна) & 500 & 2,26 & 28 & 63,28 & 72,8 & 0,87 \\
\hline Ципрофрлоксацин таб. п/о 250 мг № 10 (Технолог, Україна) & 500 & 2,69 & 28 & 75,32 & 72,8 & 1,03 \\
\hline Ципрофрлоксацин таб. п/о 500 мг № 10 (Технолог, Україна) & 500 & 2,68 & 28 & 75,04 & 72,8 & 1,03 \\
\hline $\begin{array}{l}\text { Цифрран таб. п/о } 500 \text { мг № } 10 \text { (Сан Фармасьютикал Індастріз } \\
\text { Лімітед, Індія) }\end{array}$ & 500 & 7,05 & 28 & 197,40 & 72,8 & 2,71 \\
\hline $\begin{array}{l}\text { Цитерал® таб. п/о } 500 \text { мг № } 10 \text { (Алкалоїд АД - Скоп’є, Республіка } \\
\text { Північна Македонія) }\end{array}$ & 500 & 7,07 & 28 & 197,96 & 72,8 & 2,72 \\
\hline Медоциприн таб. п/о 500 мг № 10 (Медокемі лтД, Кіпр0) & 500 & 7,81 & 28 & 218,68 & 72,8 & 3,00 \\
\hline $\begin{array}{l}\text { Цитерал® таб. п/о } 250 \text { мг № } 10 \text { (Алкалоїд АД - Скоп’є, Республіка } \\
\text { Північна Македонія) }\end{array}$ & 500 & 7,90 & 28 & 221,20 & 72,8 & 3,04 \\
\hline $\begin{array}{l}\text { Флапрокс таб. п/о } 500 \text { мг № } 10 \text { (Біофрарма Ілач Сан.ве Тідж. А.Ш., } \\
\text { Туреччина) }\end{array}$ & 500 & 8,46 & 28 & 236,88 & 72,8 & 3.25 \\
\hline Ципролет® таб. п/о 500 мг № 10 (Д-р Редді'с Лабораторіс Лтд, Індія0 & 500 & 9,03 & 28 & 252,84 & 72,8 & 3,47 \\
\hline $\begin{array}{l}\text { Цифрран OD таб. пролонг. п/о } 500 \text { мг № } 5 \text { (Сан Фармасьютикал } \\
\text { Індастріз Лімітед, Індія) }\end{array}$ & 500 & 9,57 & 28 & 267,96 & 72,8 & 3,68 \\
\hline Ципринол® таб. п/о 500 мг № 10 (КRКА, д.Д., Ново место, Словенія) & 500 & 11,04 & 28 & 309,12 & 72,8 & 4,25 \\
\hline Ципринол® таб. п/о 250 мг № 10 (KRКА, д.Д., Ново место, Словенія) & 500 & 18,18 & 28 & 509,04 & 72,8 & 6,99 \\
\hline \multicolumn{7}{|l|}{$\begin{array}{ll} & \text { Serenoa repens } \\
\end{array}$} \\
\hline $\begin{array}{l}\text { Простаплант Форте капс. №60 (Др. Вільмар Швабе ГмбХ і Ко. КГ, } \\
\text { Німеччина }\end{array}$ & $\begin{array}{c}2 \\
\text { капс. }\end{array}$ & 14,01 & 90 & 1260,90 & 76,7 & 16,44 \\
\hline $\begin{array}{l}\text { Простаплант капс. } 320 \text { мг №30 (Др. Вільмар Швабе ГмбХ і Ко. КГ, } \\
\text { Німеччина) }\end{array}$ & 320 & 10,84 & 90 & 975,60 & 76,7 & 12,72 \\
\hline Простамол ${ }^{\circledR}$ уно капс. 320 мг №30 (Берлін-хемі АГ, Німеччина) & 320 & 7,56 & 90 & 680,40 & 76,7 & 8,87 \\
\hline \multicolumn{7}{|l|}{ Фінастерид } \\
\hline Аденостерид-Здоров’я таб. п/о 5мг № 30 (Здоров'я, Україна) & 5 & 7,25 & 180 & 1305,36 & 75,0 & 17,40 \\
\hline Простан таб. п/о 5мг №30 (Технолог, Україна) & 5 & 7,99 & 180 & 1438,20 & 75,0 & 19,18 \\
\hline Пенестер® таб. п/о 5мг №30 (Зентіва, Чеська Республіка) & 5 & 9,51 & 180 & 1711,80 & 75,0 & 22,82 \\
\hline Проскар таб. п/о 5 мг № 28 (Мерк Шарп і Доум Б.В., Нідерланди) & 5 & 55,05 & 180 & 9909,00 & 75,0 & 132,12 \\
\hline \multicolumn{7}{|l|}{$\begin{array}{ll} & \text { Тамсулозин } \\
\end{array}$} \\
\hline Уримак капс. 0,4 мг № 30 (Маклеодс Фармасьютикалс Лімітед, Індія) & 0,4 & 3,01 & 30 & 90,30 & 74,5 & 1,21 \\
\hline Омікс капс. 0,4мг №30 (Технолог, Україна) & 0,4 & 3,55 & 30 & 106,50 & 74,5 & 1,43 \\
\hline Тамсулостад капс. 0,4мг №30 (Стада Арцнайміттель АГ, Німеччина) & 0,4 & 3,61 & 30 & 108,22 & 74,5 & 1,45 \\
\hline Фокусин капс. 0,4 мг №30 (Зентіва, Чеська Республіка) & 0,4 & 3,75 & 30 & 112,50 & 74,5 & 1,51 \\
\hline Тамсулід капс. 0,4 мг № 30 (Борщагівський ХФЗ, Україна) & 0,4 & 3,94 & 30 & 118,20 & 74,5 & 1,59 \\
\hline Омнік® капс. 0,4 мг №30 (Астеллас Фарма Юроп Б.В., Нідерланди) & 0,4 & 4,73 & 30 & 141,90 & 74,5 & 1,90 \\
\hline Аденорм капс. 0,4мг №30 (Київський вітамінний завод, Україна) & 0,4 & 4,77 & 30 & 143,10 & 74,5 & 1,92 \\
\hline Тамсін фрорте таб. 0,4 мг № 30 (Сінтон Хіспанія, С.Л., Іспанія) & 0,4 & 6,43 & 30 & 192,93 & 74,5 & 2,59 \\
\hline Таніз® капс. 0,4мг №30 (КРКА д.Д., Ново место, Словенія) & 0,4 & 6,97 & 30 & 209,10 & 74,5 & 2,81 \\
\hline $\begin{array}{l}\text { Флосін® капс. 0,4 мг № } 10 \text { (Фамар А.В.Е. Антоусса Плант, Греція, } \\
\text { Роттендорфр Фарма ГмбХ, Німеччина+Менаріні-Фон Хейден ГмбХ, } \\
\text { Німеччина+Сінтон Хіспанія С.Л., Іспанія) }\end{array}$ & 0,4 & 11,16 & 30 & 334,80 & 74,5 & 4,49 \\
\hline
\end{tabular}

ISSN 2312-0967. Pharmaceutical review. 2019. № 2 
Продовження табл. 4

\begin{tabular}{|c|c|c|c|c|c|c|}
\hline 1 & 2 & 3 & 4 & 5 & 6 & 7 \\
\hline Тамсол® капс. 0,4 мг №30 (Гедеон Ріхтер, Угорщина) & 0,4 & 11,34 & 30 & 340,20 & 74,5 & 4,57 \\
\hline $\begin{array}{l}\text { Омнік окас таб. п/о 0,4 мг №30 (Астеллас Фарма Юроп Б.В.. } \\
\text { Нідерланди) }\end{array}$ & 0,4 & 15,91 & 30 & 477,30 & 74,5 & 6,41 \\
\hline \multicolumn{7}{|l|}{ Силодозин } \\
\hline $\begin{array}{l}\text { Урорек капс. } 4 \text { мг №30 (Рекордаті Індустріа Хіміка е Фармасевтіка } \\
\text { С.п.А, Італія) }\end{array}$ & 4 & 7,81 & 84 & 656,04 & 56,0 & 11,72 \\
\hline \multicolumn{7}{|l|}{$\begin{aligned} & \text { Рофекоксиб } \\
&\end{aligned}$} \\
\hline Денебол таб. 50мг №10 (Мілі Хелскаре, Велика Британія) & 50 & 11,89 & 10 & 118,90 & 79,0 & 1,51 \\
\hline
\end{tabular}

тхкер пвт Лтд, Індія) (CER = 10,27). При цьому ТН Левофрлоксацину (Левофлоксацин-Тева, Левофрлоксацин Здоров'я, Леволет Д-р Редді'с), які присутні в довідниках з еквівалентності, $є$ теж корисними 3 погляду вартість/ефективність.

Поміж ТН Ципрофрлоксацину найкращим $є$ Ципроорлоксацин таб. 250 мг № 10 (ДЗ «ГНЦЛС», Україна) $(C E R=0,87)$ на відміну від Ципринолу ${ }^{\circledR}$ таб. 250 мг № 10 (KRKA, Д.Д., Ново место, Словенія) $(C E R=6,99)$.

3-поміж ТН Тамсулозину найбільш вигідним є Уримак капс. 0,4 мг № 30, Маклеодс Фармасьютикалс Лімітед, Індія $(C E R=1,21)$, а найменш - Омнік окас таб. 0,4 мг № 30 (Астеллас Фарма Юроп Б.В., Нідерланди) $(C E R=6,41)$.

При лікуванні фрітопрепаратами більш ефективним і менш витратним $€$ Простамол ${ }^{\circledR}$ уно капс. 320 мг № 30 (Берлін-хемі АГ, Німеччина) (CER = 8,87), а найменш показаним - Простаплант Форте капс. № 60 (Др. Вільмар Швабе ГмбХ і Ко. КГ, Німеччина) $(C E R=16,44)$.

I3 ТН Фінастериду найкращим $€$ АденостеридЗдоров'я таб. 5 мг № 30 (Здоров'я, Україна) (CER = 17,40). Закономірно, що оригінальний лЗ Проскар таб. 5 мг № 28 (Мерк Шарп і Доум Б.В., Нідерланди) $\epsilon$ дуже вартісним і його показник витрати/едективність $€$ надзвичайно високим порівняно з іншими ЛЗ $(C E R=132,12)$. Для цих двох ЛЗ визначені рівні еквівалентності.

Для ТН Силодозину (Урореку капс. 4 мг № 30, Рекордаті Індустріа Хіміка е Фармасевтіка С.п.А, Італія) встановлено порівняно високе значення CER $(11,72)$, а для ТН Рофекоксибу (Денеболу таб. 50 мг № 10, Мілі Хелскаре, Велика Британія) - низьке $(1,51)$.
Висновки. 1. Унаслідок упорядкування інфрормації КД щодо застосування ЛЗ при лікуванні ХП, встановлено що клінічна ефективність АБ складає 92,093,5 \% (Левофрлоксацин) і 72,8-76,8 \% (Ципрофрлоксацин), ПП - від 56,0 \% (Силодозин) до 76,7 \% (ЛЗ Serenoa repens), НПЛЗ Рофрекоксибу - 79,0 \%.

2. Ймовірність настання клінічного есректу значно вища від ймовірності, що такий ефект не спостерігатиметься, при лікуванні ХП АБ (O = 2,68...14,38) і ПП $(O=1,27 \ldots 3,29)$. При цьому найкращий результат характерний для АБ Левофрлоксацину, помітно кращий для ПП Serenoa repens, Фінастериду та Тамсулозину.

3. За співвідношенням вартість/ефективність встановлено, що станом на січень 2019 р. спостерігається клініко-економічна перевага застосування:

- в АБ поміж ТН Левофрлоксацину у Левофлоксацину таб. 500 мг № 14 (Астрафрарм, Україна) і ТН Ципрофрлоксацину - Ципрофрлоксацину таб. 250 мг № 10 (ДЗ «ГНЦЛС», Україна); серед ТН Левофрлоксацину, для яких вказані рівні еквівалентності, найкращими за показником CER був Левофлоксацин-Тева таб. п/о 500 мг №10 (Актавіс лтД, Мальта);

- у ПП серед ТН Тамсулозину в Уримака капс. 0,4 мг № 30 (Маклеодс Фармасьютикалс Лімітед, Iндія), ТН Фінастериду - Аденостерида-Здоров'я таб. 5 мг № 30 (Здоров'я, Україна) і ТН фрітопрепаратів Простамола ${ }^{\circledR}$ уно капс. 320 мг № 30 (Берлін-хемі АГ, Німеччина); при цьому для Аденостерида-Здоров'я таб. 5 мг № 30 (Здоров'я, Україна) встановлений рівень еквівалентності.

Конфрлікт інтересів: відсутній.

Conflicts of interest: authors have no conflict of interest to declare.

ISSN 2312-0967. Фармацевтичний часопис. 2019. № 2 


\title{
СТАТИСТИЧЕСКАЯ И ФАРМАКОЭКОНОМИЧЕСКАЯ ХАРАКТЕРИСТИКА РЕЗУЛЬТАТОВ КЛИНИЧЕСКИХ ИССЛЕДОВАНИЙ ЛЕЧЕНИЯ ХРОНИЧЕСКОГО ПРОСТАТИТА
}

\author{
И. В. Гадяк' \\ Ивано-Франковский национальный медицинский университет ${ }^{1}$ \\ Львовский национальный медицинский университет имени Данила Галицкого 2 \\ igadyak@ukr.net, hromovyk@gmail.com
}

Цель работы. Статистическое обобщение данных клинических исследований (КИ) лекарственных средств (ЛС), используемых при лечении хронического простатита (ХП), а также их фрармакоэкономическая оценка.

Материалы и методы. Материалами исследования выступили: сведения Кокрановской базы контролируемых исследований и веб-ресурса Medline/PubMed Национальной медицинской библиотеки США за 1995-2012 гг. по клинической эфрфективности и безопасности антибиотиков (АБ), простатопротекторов (ПП) и нестероидных противовоспалительных ЛС (НПЛС) при лечении ХП; данные Оранжевой книги Управления по контролю качества пищевых продуктов и ЛС США (ОВ), протоколов Комитета по ЛС для человека Европейского агентства ЛС (СНМР) и Rx index - Справочника эквивалентности ЛС о терапевтической эквивалентности и/или биоэквивалентности лС; информация программного комплекса «Аптека» состоянием на январь 2019 о минимальных закупочных ценах лС. Использованы методы инорормационного поиска, анализа и синтеза, статистики и фрармакоэкономики, показатель «шансы», а также индекс ХП Национального института здоровья США для оценки симптомов в КИ (NIH-CPSI).

Результаты и обсуждения. Упорядочено данные опубликованных рецензируемых, рандомизированных, плацебо-контролируемых КИ с использованием NIH-CPSI как результата по применению АБ, ПП и НПЛС при ХП. Статистическое обобщение показывает, что шансы АБ больше единицы и находятся в границах 2,68...14,38, а шансы АБ и ПП в КИ находятся в пределах 2,68...14,38 и 1,27...3,29 соответственно, то есть клинический эффект быстрее наступит, чем не насупит. Установлено, что при применении Рофекоксиба (шансы $=3,76$ ) тоже есть вероятность наступления клинического эффректа.

Систематизирована информация об эквивалентности АБ, ПП и НПЛС для лечения ХП, которые зарегистрированы В Украине. Установлено, что 3 торговых названия (ТН) Левофрлоксацина (среди них одна ТН в двух дозах) присутствуют в списке Rx index. При этом лишь Левофлоксацин-Тева таб. 500 мг № 10 (Актавис ЛтД, Мальта) находится в двух перечнях (OB и Rx index). Кроме этого, показано, что ЛС из подгруппы Силодозина имеются только в перечне CHMP. В подгруппе Финастерид одно ЛС Аденостерид-Здоровье таб. 5 мг №30 (Здоровье, Украина) присутствует в Rx index, зато лС Проскар таб. 5 мг № 28 (Мерк Шарп и Доум Б.В., Нидерланды) - в двух исследуемых перечнях (OВ и Rx index).

Вычислено показатель «затраты/эффеективность» для ТН Левофрлоксацина, Ципрофрлоксацина, Тамсулозина, Serenoa repens, Финастерида, Силодозина и Рофекоксиба. Причем в АБ использовали самый низкий показатель клинической эффрективности, а именно для Левофрлоксацина - 92,0 \%, ципрофлоксацина - 72,8 \%, а в ПП - для ТН, в которых клиническая эфрфективность более $70 \%$.

Выводы. В результате упорядочнения информации клинических исследований по применению лС при лечении ХП, установлено, что клиническая эфрфективность АБ составляет 92,0-93,5 \% (Левофрлоксацин) и 72,8-76,8 \% (Ципрофрлоксацин), ПП - от 56,0 \% (Силодозин) до 76,7 \% (ЛС Serenoa repens), НПЛС Рофрекоксиба - 79,0 \%. Выявлено, что вероятность наступления клинического эффекта значительно больше вероятности того, что такой эфрфект не будет наблюдаться, при лечении ХП АБ (шансы = 2,68...14,38) и ПП (шансы = 1,27...3,29). При этом самый лучший результат характерен для АБ Левофлоксацина, заметно лучший - для ПП Serenoa repens, Финастерида и Тамсулозина. По соотношению затраты/эффективность определено, что на январь 2019 наблюдается клиникоэкономическое преимущество применения: среди ТН Левофрлоксацина в Левофлоксацина таб. 500 мг № 14 (Астрафрарм, Украина) и ТН Ципрофрлоксацина - Ципрофрлоксацина таб. 250 мг № 10 (ОЗ «ГНЦЛС», Украина); среди ТН Тамсулозина в Уримака капс. 0,4 мг № 30 (Маклеодс Фармасьютикалс Лимитед, Индия), ТН Финастерида Аденостерида-Здоровье таб. 5 мг № 30 (Здоровье, Украина) и ТН фритопрепаратов - Простамола ® уно капс. 320 мг № 30 (Берлин-Хеми АГ, Германия).

Ключевые слова: хронический простатит; антибиотики; противовоспалительные средства; простатопротекторы; клиническая эффрективность; эквивалентность; показатель «шансы», показатель «затраты/эфффективность».

ISSN 2312-0967. Pharmaceutical review. 2019. № 2 


\title{
STATISTICAL AND PHARMACOECONOMIC CHARACTERISTICS OF THE RESULTS OF CLINICAL RESEARCHES OF CHRONIC PROSTATITIS TREATMENT
}

\author{
I. V. Gadyak, B. P. Hromovyk \\ Ivano-Frankivsk National Medical University \\ Danylo Halytsky Lviv National Medical University \\ igadyak@ukr.net,hromovyk@gmail.com
}

The aim of the work. Statistical summary of clinical trials (CT) of drugs used in the treatment of chronic prostatitis (CP) as well as their pharmacoeconomic evaluation.

Materials and Methods. The materials of the study were: information of the Cochrane database on controlled trials and the Medline/PubMed website of the National Medical Library of the United States for 1995-2012 on the efficacy and safety of antibiotics (ABs), prostate protectors (PPS) and non-steroidal anti-inflammatory drugs (NSAIDs) in the treatment of $\mathrm{CP}$; data from the Orange Book of the US Food and Drug Administration (OB); protocols of the Committee of Medicines for Humans of the European Medicines Agency (CHMP) and Rx index - Manual on the Equivalence of Medicines on the therapeutic equivalence and/or bioequivalence of medicines; information of the software complex "Pharmacy" dated January 2019 on the minimum purchase prices of drugs.

The methods of information search, analysis and synthesis, statistics and pharmacoeconomics, indicator "odds" as well as the index of CP of the US National Institute of Health (NIH-CPSI) were used for the evaluation of symptoms in CT.

Results and Discussion. The results of published reviewed, randomized, placebo-controlled CT were arranged with the use of NIH-CPSI as a result of the ABs, PPs and NSAIDs application in the treatment of CP. The statistical generalization shows that the indicator "odds" (O) of ABs and PPs in the CT are more than 1 and range from 2.68 to 14.38 and from 1.27 to 3.29 respectively, which means that the clinical effect is more likely to observe. In the use of Rofecoxib $(O=3.76)$ also has the probability of clinical effect manifestation.

Information on the equivalence of ABs, PPs and NSAIDs registered in Ukraine for the treatment of CP was systematized. It was established that 3 trade names (TN) of Levofloxacin (one of them is in two doses) are present in the list of Rx index. However, it was found that Levofloxacin-Teva tab. $500 \mathrm{mg}$ No. 10 (Actavis LTD, Malta) is present in two of the reviewed lists (OB and $\mathrm{Rx}$ index).

In addition, it was shown that the drugs from the subgroup of Silodosin are available only in the list of CHMP. In the Finasteride subgroup one drug Adenosteride-Zdorovye tab. $5 \mathrm{mg}$ No.30 (Zdorovye, Ukraine) is present in the Rx index, but Proskar tab. 5 mg No. 28 (Merck Sharp and Dohme B.V., Nederlands) is present in two studied lists (OB and Rx index). The cost/effectiveness ratio index for TN Levofloxacin, Ciprofloxacin, Tamsulosin, Serenoa repens, Finasteride, Silodosin and Rofecoxib was calculated. At the same time, the lowest rate of clinical efficacy was used for ABs, namely, for Levofloxacin - 92.0 \%, Ciprofloxacin - $72.8 \%$, and in PPs - for TN, which showed clinical efficacy more than $70 \%$.

Conclusions. As a result of summarizing of clinical trials data on the use of drugs for the treatment of CP it was established that clinical efficacy of ABs is 92.0-93.5\% (Levofloxacin) and 72.8-76.8\% (Ciprofloxacin); of PPs is from 56.0 \% (Silodosin) to $76.7 \%$ (Serenoa repens); of NSAID Rofecoxib is $79.0 \%$. It was found that the probability of clinical effect manifestation is much greater in the treatment of $C P$ with $A B s(O=2.68 \ldots 14.38)$ and PPs $(O=1.27 \ldots 3.29)$. At the same time, the best result is characteristic for $A B$ Levofloxacin and it is noticeably better for such PPs as Serenoa repens, Finasteride and Tamsulosin. The cost/efficiency ratio shows that in January 2019 clinical and economic advantage of use of such drugs was obsedved: in the group of ABs among the Levofloxacin trade names for Levofloxacin tab. 500 mg No. 14 (Astrafarm, Ukraine) and among the Ciprofloxacin trade names for Ciprofloxacin tad. 250 mg No.10 (DZ GNCLS, Ukraine); in the group of PPs among the Tamsulosin trade names for Urimak caps. $0.4 \mathrm{mg}$ No. 30 (Macleods Pharmaceuticals Ltd, India), among the Finasteride trade names for Adenosterid-Zdorovye tad. $5 \mathrm{mg}$ No. 30 (Zdorovye, Ukraine) and among the trade names of herbal medicines for Prostamol® uno caps. 320 mg No. 30 (Berlin-Chemi AG, Germany).

Key words: chronic prostatitis; antibiotics; non-steroidal anti-inflammatory drugs; prostate protectors; clinical efficacy; equivalence; indicator "odds"; cost/efficiency ratio.

\section{Список літератури}

1. How common is prostatitis? A national survey of physician visits / M. McNaughton-Collins, R. S. Stafford, M. P. O'Leary, M. J. Barry // Journal of Urology. - 1998. - No.159. - P. 1224-1228. DOI: https://doi.org/10.1016/ S0022-5347(01)63564-X.

2. Category III chronic prostatitis/chronic pelvic pain syndrome: Insights from the National Institutes of Health
Chronic Prostatitis Collaborative Research Network Studies / J. C. Nickel, R. B. Alexandr, R. Anderson [et al.] // Current Urology Reports. - 2008. - No. 9 (4). P. 320-327. DOI: https://doi.org/ 10.1007/s11934-0080055-7.

3. Литвинець $€$. А. Сучасні погляди на патогенез, діагностику і напрямки медикаментозного впливу

ISSN 2312-0967. Фармацевтичний часопис. 2019. № 2 
у хворих на хронічний простатит / Є. А. Литвинець // Галицький лікарський вісник. - 2004. - № 4. - С. 114-118.

4. Nickel J. C. Research guidelines for chronic prostatitis: consensus report from the first National Institutes of Health International Prostatitis Collaborative Network / J. C. Nickel, L. M. Nyberg, M. Hennenfent // Urology. 1999. - No. 54. P. 229-233.

5. Orange Book: Approved Drug Products with Therapeutic Equivalence Evaluations. URL: http://www.accessdata. fda.gov/scripts/cder/ob (Last accessed: 11.01.2019).

6. European Medicines Agency Available from: URL : http:// www.ema.europa.eu/en/search/search (Last accessed: 11.01.2019)

7. Зупанець I. A. Rx index - Довідник еквівалентності лікарських засобів / за ред. І. А. Зупанця та В. П. Черниха. - Київ : Фармацевт Практик, 2016. - 848 c.

8. Програмний комплекс «Аптека»: веб-сайт. URL: https : I/ pharmbase.com.ua/uk/optovi-propozitsiyi/ (дата звернення: 14.01.2019)

9. Krieger J. N. NIH consensus definition and classification of prostatitis / J. N. Krieger, L. Nyberg, J. C. Nickel // JAMA. - 1999. - No. 282. - P. 236-237.

10. Responsiveness of the National Institutes of Health. Chronic Prostatitis Symptom Index (NIH-CPSI) / K. J. Propert, M. Litwin, Y. Wang [et al.] // Quality of Life Research. - 2006. - No. 15. - P.299-305. DOI: https:// doi.org/ 10.1007/s11136-005-1317-1.

11. Рожко М. М. Застосування теорії шансів для оцінки ефрективності ендодонтичного лікування коренів зубів / М. М. Рожко, Н. С. Іванова // Архів клінічної медицини. - 2012. - № 1 (18). - С. 78-81.

12. Штабинская Т. Т. Ангиогенез в аденокарциноме толстой кишки : монография / Т. Т. Штабинская, В. А. Басинский, С. А. Ляликов. - Гродно : ГрГМУ, 2018. $132 \mathrm{c}$.

13. Яковлєва Л. В. Фармакоекономіка: навч. посібник для студентів вузів / за ред. Л. В. Яковлєвої. Вінниця : Нова Книга, 2009. - 208 с.

14. Wagenlehner F. Practice management of chronic bacterial prostatitis with levofloxacin / F. Wagenlehner, K. Roscher, K. G. Naber // Aktualle Urology. - 2011. No. 42 (3). - P. 184-189. DOI: https://doi.org/ 10.1055/ s-0031-1271439.

15. Oral levofloxacin $500 \mathrm{mg}$ once daily in the treatment of chronic bacterial prostatitis / K. G. Naber, K. Roscher,

\section{References}

1. McNaughton-Collins M, Stafford RS, O'Leary MP, Barry $\mathrm{MJ}$. How common is prostatitis? A national survey of physician visits. Urol. 1998;159: 1224-8. Available from: http://dx.doi.org/10.1016/S0022-5347(01)63564-X.

2. Nickel JC, Alexandr RB, Anderson R, et al. Category III chronic Prostatitis/Chronic Pelvic Pain Syndrome: Insights from The National Institutes of Health Chronic Prostatitis Collaborative Research Network Studies. Urol Rep. 2008; 9(4): 320-7. Available from: http:// dx.doi.org/10.1007/s11934-008-0055-7.
H. Botto, V. Schaefer // International Journal of Antimicrobial Agents. - 2008. - No. 32 (2). - P. 145-153. DOI: https://doi.org/10.1016/j.ijantimicag.2008.03.014.

16. Treatment of chronic bacterial prostatitis with levofloxacin and ciprofloxacin lowers serum prostate specific antigen / A. J. Schaeffer, S. C. Wu, A. M. Tennenberg, J. B. Kahn // Journal of Urology. - 2005. 174 (1). - P. 161-164. DOI: https://doi.org/10.1097/01. ju.0000162017.24965.2b.

17. Ciprofloxacin in the treatment of chronic bacterial prostatitis / M. F. Trapeznikova, K. I. Savitskaia, A. al-Suri, A. G. Nekhorosheva // Urol. Nefrol. (Mosk). - 1995. No 5. - P. 20-23.

18. Efficiency and safety of prostamol-Uno in patients with chronic abacterial prostatitis / lu. G. Aliaev, A. Z. Vinarov, K. L. Lokshin, L. G. Spivak // Urology. - 2006. No. 1. - P. 47-50.

19. A randomized placebo-controlled multicentre study to evaluate the safety and efficacy of finasteride for male chronic pelvic pain syndrome (category III A chronic nonbacterial prostatitis) / J. C. Nickel, J. Downey, M. A. Pontari [et al.] // BJU Internacional Jurnal. - 2004. - No. 93 (7). - P. 991-1005.

20. Chen $X$. S. Tamsulosin for the treatment of chronic. abacterial prostatitis / X. S. Chen, Z. Q. Ye, X. Y. Zeng // Zhonghua Nan Ke Xue. - 2002. - No. 8 (1). - P. 51-53.

21. Alfuzosin treatment for chronic prostatitis/chronic pelvic pain syndrome: a prospective, randomized, doubleblind, placebo-controlled, pilot study / A. Mehik, P. Alas, J. C. Nickel [et al.] // Urology. - 2003. - No. 62 (3). P. 425-429.

22. Terazosin therapy for chronic prostatitis/chronic pelvic pain syndrome: a randomized, placebo controlled trial / P. Y. Cheah, M. L. Liong, K. H. Yuen [et al.] // Journal of Urology. - 2003. - No. 169. - P. 592-606.

23. Silodosin for men with chronic prostatitis/chronic pelvic pain syndrome: results of a phase II multicenter, double-blind, placebo controlled study / J. C. Nickel, M. P. O'Leary, H. Lepor [et al.] // Urology. - 2011. No. 186 (1). - P. 125-131. DOI: https://doi.org/10.1016/j. juro.2011.03.028.

24. A randomized, placebo-controlled, multicenter study to evaluate the safety and efficacy of rofecoxib in the treatment of chronic nonbacterial prostatitis / J. C. Nickel, M. Pontari, T. Moon [et al.] // Journal of Urology. - 2003. - No. 169. - P. 1401-1405. DOI: https://doi.org/10.1097/01.ju.0000054983.45096.16.

3. Lytvynets YeA. Modern views on pathogenesis, diagnostics and directions of medical influence in patients with chronic prostatitis. Halytskyi likarskyi visn. 2004;4: 114-8. Ukrainian.

4. Nickel JC, Nyberg LM, Hennenfent M. Research guidelines for chronic prostatitis: consensus report from the first National Institutes of Health International Prostatitis Collaborative Network. Urol. 1999;54: 229-33.

5. Orange Book: Approved Drug Products with Therapeutic Equivalence Evaluations. Available from: https://www.

ISSN 2312-0967. Pharmaceutical review. 2019. № 2 
accessdata.fda.gov/scripts/cder/ob.

6. European Medicines Agency. Available from: https:// www.ema.europa.eu/en/search/search

7. Zupanets IA, Chernykh VP. Handbook of equivalence of medicines. [Довідник еквівалентності лікарських засобів] Kyiv: Farmatsevt Praktyk; 2016. Ukrainian.

8. Program complex "Pharmacy". Available from: https:// pharmbase.com.ua/uk/optovi-propozitsiyi/.

9. Krieger JN, Nyberg L, Jr, Nickel JC. NIH consensus definition and classification of prostatitis. JAMA. 1999;282: 2367.

10. Propert KJ, Litwin M, Wang $\mathrm{Y}$, et al. Responsiveness of the National Institutes of Health. Chronic Prostatitis Symptom Index (NIH-CPSI) Qual Life Res. 2006;15:299305. Available from: http://dx.doi.org/10.1007/s11136005-1317-1.

11. Rozhko MM, Ivanova NS. Application of odds ratio to assess the efficiency of root canal treatment. Arkhiv klin medytsyny. 2012;1(18): 78-81. Ukrainian.

12. Shtabinskaya TT, Basinskiy VA, Lyalikov SA. Angiogenesis in adenocarcinoma of the colon. Monograph. [Ангиогенез в аденокарциноме толстой кишки: монографрия] Grodno: GrGMU; 2018. Russian.

13. Yakovleva LV. Pharmacoeconomics: for university students. [Фармакоекономіка: навч. посібник для студентів вузів] Vinnytsia: Nova Knyha; 2009. Ukrainian.

14. Wagenlehner F, Roscher K, Naber KG. Practice management of chronic bacterial prostatitis with levofloxacin. Aktualle Urol. 2011;42(3): 184-9. Available from: http://dx.doi.org/ 10.1055/s-0031-1271439.

15. Naber KG, Roscher K, Botto H, Schaefer V. Oral levofloxacin $500 \mathrm{mg}$ once daily in the treatment of chronic bacterial prostatitis. Int J Antimicrob Agents. 2008;32(2): 145-53. Available from: http://dx.doi.org/: 10.1016/j.ijantimicag.2008.03.014.

16. Schaeffer AJ, Wu SC, Tennenberg AM, Kahn JB. Treat- ment of chronic bacterial prostatitis with levofloxacin and ciprofloxacin lowers serum prostate specific antigen. Urol. 2005;174(1): 161-4. Available from: http:// dx.doi.org/: 10.1097/01.ju.0000162017.24965.2b.

17. Trapeznikova MF, Savitskaia KI, al-Suri A, Nekhorosheva AG. Ciprofloxacin in the treatment of chronic bacterial prostatitis. Urol Nefrol (Mosk). 1995(5): 20-3.

18. Aliaev luG, Vinarov AZ, Lokshin KL, Spivak LG. Efficiency and safety of prostamol-Uno in patients with chronic abacterial prostatitis. Urol. 2006;1: 47-50. Russian.

19. Nickel JC, Downey J, Pontari MA, et al. A randomized placebo-controlled multicentre study to evaluate the safety and efficacy of finasteride for male chronic pelvic pain syndrome (category III A chronic nonbacterial prostatitis). BJU Int. 2004;93(7): 991-5.

20. Chen XS, Ye ZQ, Zeng XY. Tamsulosin for the treatment of chronic abacterial prostatitis. Zhonghua Nan Ke Xue. 2002;8(1): 51-3.

21. Mehik A, Alas P, Nickel JC, Sarpola A, Helström PAlfuzosin treatment for chronic prostatitis/chronic pelvic pain syndrome: a prospective, randomized, double-blind, placebo-controlled, pilot study. J Urology. 2003;62(3): 425-9.

22. Cheah PY, Liong ML, Yuen $\mathrm{KH}$ et al. Terazosin therapy for chronic prostatitis/chronic pelvic pain syndrome: a randomized, placebo controlled trial. J Urol. 2003; 169: 592-6.

23. Nickel JC, O'Leary MP, Lepor $\mathrm{H}$, et al. Silodosin for men with chronic prostatitis/chronic pelvic pain syndrome: results of a phase II multicenter, double-blind, placebo controlled study. Urol. 2011; 186(1): 125-31. Available from: http://dx.doi.org:10.1016/j.juro.2011.03.028.

24. Nickel JC, Pontari M, Moon T et al. A randomized, placebo-controlled, multicenter study to evaluate the safety and efficacy of rofecoxib in the treatment of chronic nonbacterial prostatitis. Urol. 2003; 169:1401-5 Available from: http://dx.doi.org:10.1097/01.ju.0000054983.45096.16

\section{Відомості про авторів:}

Гадяк І. В. - асист. кафредри фрармації, Івано-Франківський національний медичний університет, м. ІваноФранківськ, Україна. E-mail: igadyak@ukr.net, ORCID: 0000-0001-8818-4868.

Громовик Б. П. - д. фрармац. н., профр., завідувач кафредри організації та економіки фрармації, Львівський національний медичний університет імені Данила Галицького, м. Львів, Україна. E-mail: hromovyk@gmail.com, ORCID: 0000-0002-6459-6021.

\section{Information about authors:}

Gadyak I. V. - assistant, the Pharmacy Department, Ivano-Frankivsk National Medical University, Ivano-Frankivsk, Ukraine. E-mail: igadyak@ukr.net, ORCID: 0000-0001-8818-4868.

Hromovyk B. P. - DS (Pharmacy), Professor, Head of the Organization and Economics of Pharmacy Department, Danylo Halytsky Lviv National Medical University, Lviv, Ukraine. E-mail: hromovyk@gmail.com, ORCID: 0000-00026459-6021. 